\title{
PENDIDIKAN KECAKAPAN HIDUP PEMBUATAN SENDAL HOTEL WARGA BINAAN LAPAS KLAS II SALEMBA JAKARTA
}

\author{
Dewi Rahmawaty \\ Desain Busana, Desain Produk, Sekolah Tinggi Desain Interstudi \\ email: dewi.stdi@interstudi.edu
}

\begin{abstract}
Abstrak
Penelitian ini mengkaji tentang pelaksanaan pendidikan keterampilan di Lapas Klas II Salemba tahun 2016. Adapun kajian pokoknya pada proses pembelajaran keterampilan dan efektifitas daripembelajaran tersebut. Secara umum proses pembelajaran pendidikan keterampilan dapat dikatakan baik dan lancar. Hal ini terlihat pada apa yang direncanakan narasumber bidang ketrampilan dapat berjalan sesuai dengan yang diinginkan. Kesesuaian antara metode mengajar dengan materi pelajaran sangat tepat dengan alokasi waktu yang diberikan. Sehingga hal ini menjadi indicator efektifnya proses pembelajaran keterampilan yang memadai dalam rangka mempersiapkan memasuki dunia bebas setelah keluar dari lembaga pemasyarakatan. Selain mempunyai keterampilan juga memiliki keimanan dan ketaqwaan yang kuat terhadap Tuhan Yang Maha Kuasa. Sehingga keseimbangan IPTEK dan Imtaq menjadi barometer bagi warga binaan. Penelitian ini bertujuan untuk : 1) Mengetahui proses pembelajaran a) Populasi : yang menjadi instrument dalam penelitian ini adalah Warga Binaan Lapas Klas II Salemba Jakarta b) sampel : dalam penelitian ini sampel diambil 20 warga binaan lapas Salemba 2) Waktu dan Tempat Penelitian, penelitian ini dilakukan Bulan Oktober 2017 - Oktober 2018, bertempat di Lapas salemba Jakarta, 3) Metode Penelitian; Wawancara Observasi dan Dokumentasi Hasilnya menunjukan bahwa latar belakang diselenggarakannnya pendidikan ketrampilan adalah membekali warga binaan ketrampilan kecakapan hidup yatiu sandal hotel yang diharapkan sebagai bekal warga binaan yang dapat digunakan setelah bebas dari lembaga pemasyarakatan. Sehingga aspek ini dapat dijadikan kekuatan pembebas dari kemiskinan dan keterbelakangan ekonomi. Adapun proses pelaksanaan pendidikan ketrampilan di Lapas Klas II Salemba berjalan baik dan lancar. Hal ini terlihat pada kesesuaian antara metode mengajar dengan materi dan jumlah waktu yang disediakan. Berdasarkan hal tersebut di atas dapat disimpulkan bahwa pelaksanaan pendidikan ketrampilan di Lapas Klas II Salemba Jakarta dapat dikatakan efektif pelaksanaannya karena apa yang direncanakan narasumber telah sesuai dengan tujuan pembelajaran yang diinginkan dan standar kompetensi yang dipersyaratkan.
\end{abstract}

Kata Kunci : Kecakapan Hidup, Ketrampilan, Warga Binaan, Lapas

\begin{abstract}
This research examines the implementation of vocational education in Salemba Prison Class II in 2016. The study principally on learning the skills and effectiveness of the learning. Generally speaking skills education learning process can be said to be good and smooth. It looks at what is planned resource area of skills will be implemented as desired. Kesesusian between methods of teaching the subject matter is very precise with the allocation of time given. So this became effective indicator learning process sufficient skills in order to prepare for entering the free world after coming out of the penitentiary. Besides having the skills also have strong faith and devotion to God Almighty. So that the balance of science and technology and IMTAQ be a barometer for the inmates. This study aims to: 1) Know the process of learning a) Population: that became instrumental in this research is Citizens Patronage Prison Class II Salemba b) samples: in this study samples were taken 20 prisoners prison Salemba 2) Date and place of study, research this is done in October 2017 - October 2018, at Salemba prison in Jakarta, 3) Research Methods; Interview Observation and Documentation The result showed that the background vocational education is to equip inmates skills life skills yatiu sandals which are expected as the provision of inmates that can be used after being released from a correctional institution. So that this aspect can be used as a force of liberation from poverty and economic backwardness. The process of implementation of
\end{abstract}


vocational education in Salemba Prison Class II is going well and smoothly. This looks at the match between the methods of teaching material and the amount of time provided. Based on the above it can be concluded that the implementation of vocational education in Salemba Prison Class II can be said to be effective implementation because of what is planned informants in accordance with the desired learning objectives and the required standard of competence.

Keywords : Life Skills, Handycraft, Prisoner, Prison

\section{PENDAHULUAN}

Kemajuan suatu bangsa sangat bergantung pada kualitas sumber daya manusia. Semakin baik kualitas sumber daya manusia suatu bangsa, maka semakin memiliki competitive advantage dengan Negara lain terutama di era globalisasi. Era globalisasi yang dimulai pada abad XXI dipandang sebagai era persaingan kualitas. Hal ini membawa berbagai konsekuensi baru pada berbagai bidang, terutama bidang pendidikan. Dimana pendidikan merupakan salah satu faktor utama dalam meningkatkan sumber daya manusia.

Pendidikan kecakapan hidup adalah pendidikan kemampuan, kesanggupan, dan keterampilan yang diperlukan oleh seseorang untuk menjalankan kehidupan (Slamet, 2002: 1). Sementara itu Tim BroadBased Education (2002) yang dikutip oleh Slamet (2002: 1) menafsirkan kecakapan hidup sebagai kecakapan yang dimiliki seseorang untuk mau dan berani menghadapi problema hidup dan kehidupan secara wajar tanpa merasa tertekan, kemudian secara pro-aktif dan kreatif mencari serta menemukan solusi sehingga akhirnya mampu mengatasinya. Dalam Undang Undang Republik Indonesia No. 20 tahun 2003 tentang Sistem Pendidikan Nasional pasal 26 ayat 3 menyatakan bahwa pendidikan kecakapan hidup (life skill) adalah pendidikan yang memberikan kecakapan personal, kecakapan sosial, kecakapan intelektual, dan kecakapan vokasional untuk bekerja atau usaha mandiri (Depdiknas, 2003: 59).

Keterampilan menjadi salah satu kunci sukses seseorang di masa sekarang. Aneka ragam bidang keterampilan yang selalu berkembang menjadi Dunia Industri Kerajinan semakin kreatif dari masa ke masa. Hal ini bisa dirasakan juga manfaatnya bagi warga binaan yang sedang menjalani masa di lembaga pemasyarakatan. Pendidikan ketrampilan bisa dilakukan didalam lembaga pemasyarakatan dan membantu mempersiapkan bekal untuk kehidupan berikutnya selepas bebas nanti.

Dari penelitian yang dilakukan Golman, D (1998) sebagaimana dikutip Widhiarso Wahyu (2007) menemukan bahwa kesuksesan seseorang tidak hanya didukung oleh seberapa pintar seseorang dalam menerapkan pengetahuan dan mendemonstrasikan ketrampilannya, akan tetapi seberapa besar seseorang mampu mengelola dirinya dan berinteraksi dengan orang lain. Adanya konsekeunsi tersebut, maka tidaklah terlalu berlebihan jika dikatakan bahwa pada era globalisasi ini Lapas sebagai fasilitator dalam kegiatan belajar keterampilan bagi para warga binaan diposisikan sebagai kunci utama untuk meramu sumber daya manusia yang sebelumnya berperkara menjadi SDM yang mampu lebih mandiri dan lebih kreatif untuk dapat berkompetisi didunia nyata setelah masa bebas nantinya.

Penelitian H Halimah, S Saleh, P Swissia yaitu pemberdayaan napi perempuan Lapas Way Hui Melalui Kerajinan Rajutan dan Perhitungan Penentuan Harga Jual Produk, yang menyatakan bahwa pemberdayaan narapidana perempuan dengan membekali mereka kerajinan merajut sebagai bekal mereka kelak ketika menjalani kehidupan bebas. Dalam kegiatan pelatihan tidak saja diajarkan mengenai teknik merajut dengan berbagai teknik dan rupa juga diajarkan bagaimana menghitung harga jual dari produk yang dibuat. Hal ini perlu juga menjadi bagian dalam pelatihan pengabdian masyarakat di Lapas Way Hui.

Penelitian lainnya mengenai Pelatihan Kerajinan di Lapas Kelas 2B Singaraja yang ditulis oleh MM Ansi, IW Sudiarta IN Sila meneybutkan bahwa ada peningkatan kepercayaan diri dari narapidana yang mengikuti pelatihan dan dapat memproduksi kerajinan serta menghitung harga jual dari produk yang dibuat, dari yang sebelumnya mereka ragu ragu menentukan harga jual produknya. 
Sebagaimana Lapas lainnya, Lapas Klas II Salemba merupakan pembentukan Unit Pelaksana Teknis (UPT) Lembaga Pemasyarakatan Klas IIA Salemba berdasarkan Surat Keputusan Menteri Hukum dan HAM RI No. M.02-PR.07.03 Tahun 2007.

Kegiatan pembelajaran keterampilan pada Lapas ditujukan untuk membantu warga binaan agar memiliki bekal kemampuan untuk bekerja yang dapat mendatangkan penghasilan yang layak guna memenuhi kehidupan nantinya setelah bebas. Program Giatja pada Lapas Salemba menjadikan kecakapan vokasional sebagai entry point dalam menggarap warga binaan untuk dibekali dengan berbagai kecakapan hidup yang dibutuhkan. Saat ini ketrampilan yang diajarkan adalah pembuaan sandal hotel. Kegiatan ini dilaksanakan unit Giatja yang sebelumnya menyeleksi warga binaan yang sesuai untuk diberi pelatihan lalu membentuk kelompok belajar ketrampilan pilihan/tertentu yang disesuaikan dengan minat dan kebutuhan serta peran serta fasilitator atau sumber belajar.

\section{METODE PENELITIAN}

Dalam penelitian ini pendekatan yang digunakan penulis adalah deskriptif kualitatif dan deskriptif analisis. Dengan metode Pendidikan masuarakat Hal ini dilakukan dalam rangka reprentasi objek tentang realitas yang terdapat dalam masalah yang diteliti, untuk mendeskripsikan segala hal yang berkaitan dengan pokok masalah selanjutnya dari data yang terkumpul diproses dan dianalisis.

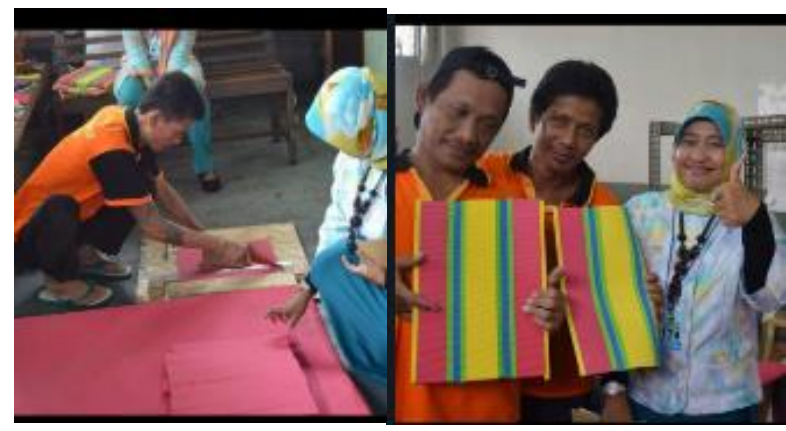

\section{Gambar 1. Melakukan Pelatihan pembuatan Sendal Hotel dengan warga binaan}

Difusi Iptek dilakukan dengan memberikan keadaan teknologi yang digunakan di lapangan (Field Research) serta penjabaran yang dilakukan untuk kemudahan penyampaian informasi terkait pembuatan sandal hotel di Lapas Salemba.

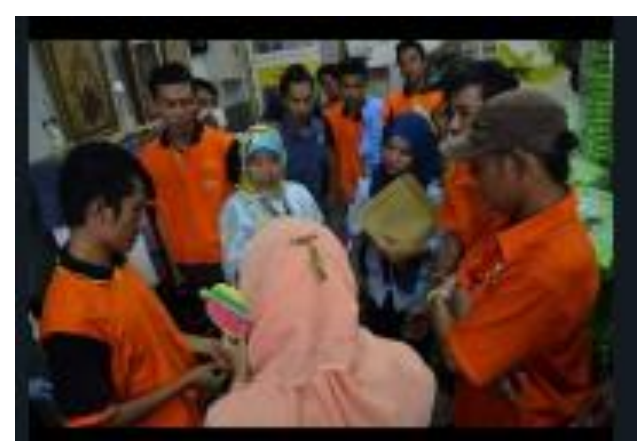

\section{Gambar 2. Sedang melakukan diskusi dengan para warga binaan}

Berdasarkan pada tujuan penelitian yang akan dicapai yaitu studi tentang proses dan efektifitas program pendidikan ketrampilan maka yang menjadi instrumen / responden dalam penelitian ini adalah instruktur dan warga binaan dalam interaksi proses belajar mengajar, maka hal Peatihan dengan demontrsasi terkait praktek pembuatan sandal hotel dan mediasi dari Yayasan Qudwah Albarosiyah 
sebagai mediator penyelenggara kegiatan Pengabdian Masyarakat pembautan sandal hotel, dilaksanakan sampai pihak lapas Salemba mendapatkan kepercayaan mengerjakan pesanan sandal hotel.

\section{HASIL DAN PEMBAHASAN}

Berdasarkan pada tujuan penelitian yang akan dicapai maka dengan menelaah seluruh data yang tersedia dari berbagai sumber yaitu observasi, wawancara, dan dokumentasi kemudian langkah selanjutnya adalah mengadakan representasi data, menyusunnya dengan satuan satuan yang kmudian dikategorikan dan diakhiri dengan analisis dan menarik kesimpulan. Dengan melihat prosedur tersebut dapat dikatakan bahwa penelitian ini menggunakan teknik analisis data berupa data deskriptif analisis.

Gambaran dari hasil pelaksanaan pendidikan ketrampilan digunakan sebagai alat untuk mengetahui seberapa besar proses pelaksanaan program ketrampilan pembuatan sandal hotel telah memenuhi proses yang efektif dalam mencapai tujuan yang direncanakan.

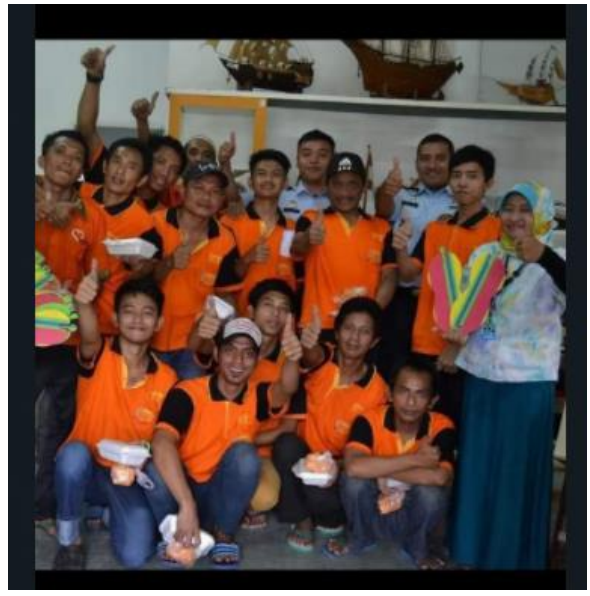

\section{Gambar 3. Melakukan Sesi Foto bersama dengan memperlihatkan hasil produk}

Untuk kepentingan penggambaran hasil dari pelaksanaan program ketrampilan pembuatan sandal hotel ini akan dilihat nilai hasil belajar warga binaan yang diperoleh melalui post test dan pendapat warga binaan tentang manfaat mengikuti pelaksanaan program ketrampilan pembuatan sandal hotel tersebut sebagai bekal saat mereka bebas untuk memperoleh pekerjaan dan perolehan tambahan pendapatan sehingga mereka mampu berusaha mandiri.

\section{A. Hasil Belajar}

Hasil belajar dari warga binaan pada pelaksanaan program ketrampilan pembuatan sandal hotel dapat diketahui dengan membandingkan kemampuan awal sebelum mengikuti pembelajaran dengan kemampuan akhir setelah mengikuti pembelajaran.

Berdasarkan data yang diperoleh dari hasil pre test dan post test pada Lapas Sakemba Jakarta dapat diketahui bahwa pada umumnya warga binaan mengalami peningkatan prestasi, yaitu lebih tingginya nilai post test dibandingkan nilai pre test.

Dari perolehan ini dapat dikatakan bahwa kemampuan penguasaan materi warga belajar program life skills pada PKBM Miftahul Jannah ini menguasai materi dengan baik. 


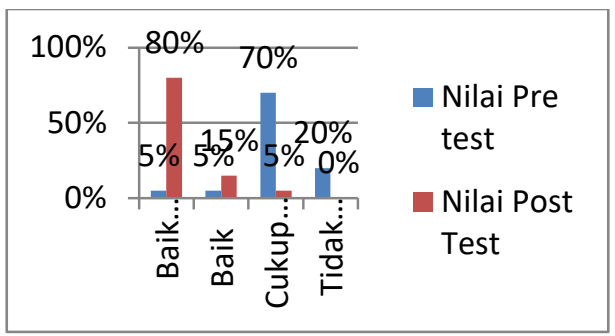

\section{Gambar 4. Perbandingan Nilai Pre test dan Post Test Program Ketrampilan Pembuatan Sandal}

\section{B. Manfaat Pembelajaran}

Seperti telah di bahas sebelumnya, Lapas Salemba memberikan sebanyak 6 materi yang pada umumnya memiliki penilaian yang tergolong baik.

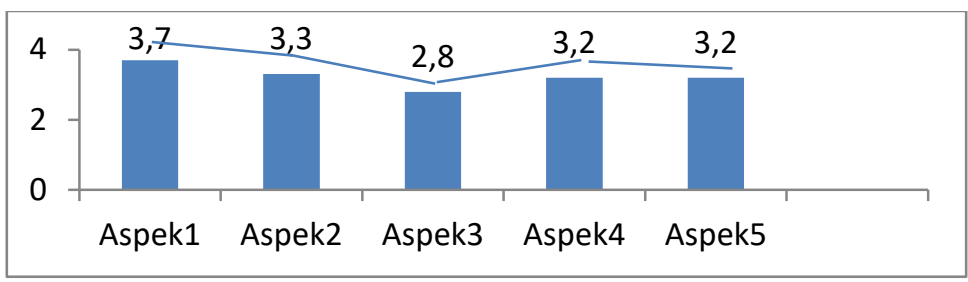

\section{Gambar 5. Penilaian WB Terhadap Materi Program Ketrampilan Pembuatan Sandal}

Penelitian tentang hasil pada penelitian ini dilakukan dengan wawancara terhadap warga binaan yang telah mengikuti program ketrampilan pembuatan sandal hotel Namun tidak semua data didapat dari hasil wawancara. Ada beberapa teknik pengambilan data dengan cara dokumentasi dan kuesioner.

Semua warga binaan program ketrampilan pembuatan sandal hotel Lapas Salemba adalah para tahanan yang sedang menjalani masa hukuman.

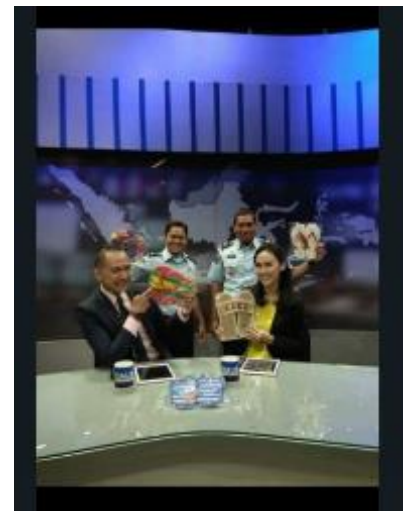

Gambar 6. Publikasi hasil produk PkM dengan Salah satu media elektronik

Secara rata-rata warga binaan memiliki pendapatan atau komisi dari hasi penjualan produk sebesar 5 persen dari harga produk. Yaitu selama sebulan pendapatan sebesar Rp. 75.000,00 atau lebih. Yaitu dari rata-rata $\mathrm{Rp} 12.500,00$ ketika sebelum mengikuti program menjadi rata-rata Rp. 75.000,00 setelah selesai mengikuti program. Jika dipresentasikan secara rata-rata responden mengalami peningkatan sebesar $300 \%$. Dilihat dari perubahan kegiatannya, umumnya warga binaan mengalami perubahan kegiatan yaitu mereka adalah tahanan dari Lapas Salemba setelah mengikuti program ketrampilan pembuatan sandal hotel mereka memiliki kegiatan lain yaitu ikut membuat produk ketrampilan di workshop lapas. Bagi warga binaan yang memiliki kompetensi dan perilaku 
yang baik akan bergabung untuk magang dengan sanggar atau workshop Lapas untuk bisa menerima pesanan dari para stakeholder. Kemudian dengan diadakannya pembelajaran tentang menjahit, mereka memperoleh tambahan ketrampilan (skills), sehingga dapat meningkatkan pendapatan.

\section{SIMPULAN}

Program keterampilan pembuatan sandal Oleh karena itu, dapat disimpulkan bahwa program keterampilan pembuatan sandal hotel pada pendidikan ketrampilan Lapas memiliki nilai manfaat yang sangat besar dan merupakan program strategis untuk mendongkrak reputasi lapas Salemba.

Kiranya sebagai penyambung estafet dari kegoatan pengabdian masyarakat di Lapas Kelas IIA Sakemba dapat dulanjutkan dengan pelatihan lainnya. Hal ini untuk bisa membantu warga binaan meningkatkan kepercayaan diri serta bekal kecakapan hidup di kemudian hari.

\section{SARAN}

Lapas merupakan institusi pemerintah di Indonesia dengan segala kelebihan dan kekurangannya. Lapas saat ini memberikan layanan pendidikan ketrampilan yang menjadi ciri khas dari lapas itu sendiri yang akhirnya mampu membuat Lapas ini menjadi suatu wadah perubah dan pemberi harapan bagi para tahanan selepas mereka bebas nantinya, sehingga diharapkan akan lahir semangat para warga binaan yang bisa berhasil, percaya diri, memiliki wawasan luas dan memiliki jati diri yang utuh serta tangguh.

\section{UCAPAN TERIMAKASIH}

Penulis mengucapkan terimakasih kepada Tim Giatja Kegiatan Kerja Balai Latihan Kerja Lembaga Pemasyarakatan (Lapas) Kelas IIA Salemba yang memberikan kesempatan penulis untuk melakukan pengabdian masyarakat serta Yayasan Qudwah Albarsoyah sebagai mediator dari terselenggaranya kegiatan pengabdian masyarakat.

\section{DAFTAR PUSTAKA}

Aisyah, Siti, 2007. Suplemen Kerajinan Tangan dan Kesenian, Jakarta : Universitas Terbuka BPS. 2015. Profil Industri Kecil dan Kerajinan Rumah Tangga: Tahun 2015, Jakarta

Gevra, O (2010) Fashion Accessories. New York : Firefly Book

Jafar HAfsah. 2004. Upaya Pengembangan Usaha Kecil dan Menengah (UKM). Infokop Nomor 25

Tahun XX

Noer Soetrisno. 2002. Pengembangan UKM, Ekonomi Rakyat dan Penanggulangan Kemiskinan. Jakarta Riello G dan Meneil, P (eds) (2011). Shoes: A Hystory Forms Sandal to Sneakers. London : Berg

Shinta, A. 2011. Manajemen Pemasaran, Malang : UB Press

Stall, C (2004). Shoes : A Lexicon of Style. Asia : Periplus editions

Sugiyono (2012) Metode Penelitian Kuantitaf dan Kualitatif dan R\&D. Bandung : Alfabeta

Syafii, dkk, 2003, Kerajinan Tangan dan Kesenian, Jakarta : Universitas Terbuka

Tambunan T 1999. Perkembangan Industri Skala Kecil di Indonesia. Jakarta : PT Mutiara Sumber Widya Tarsis Tarmudji, 1996. Prinsip Prinsip Wirausaha Yogyakarta : Liberty

Widyasari, Choiriyah, 2011. Kreativitas dan Keberbakatan, Surakarta: Qinant 